\title{
Evaluation of the Role of Gonadotropins in Regulating Differentiation of Mesenchymal Stem Cells Into Testicular Leydig Cells
}

\author{
DALIA H. ABOUELELA, M.D.; THORIA A. OMAR, M.D.; HAGER S. ABOU EL-NAGA, M.B.B.Ch. and \\ EMAN S. SHABAN, M.B.B.Ch.
}

The Department of Clinical Pathology, Faculty of Medicine, Menoufia University, Egypt

\begin{abstract}
Background: Testicular Leydig cells are the cells who responsible or testosterone hormone production which in turn is the principle male sex hormone and is responsible for reproductive growth and development in male 2 nd ry sexual characters.

Leydig cells depletion may result from different issues may be congenital, acquired as a result of trauma, radiation, chemotherapy and others which result in low testosterone level.

Transplantation of Leydig cells which obtained from Mesenchymal stem cells differentiation by effect of gonadotropins has become a main treatment modality in patients with low testosterone levels.

Aim of Study: In this study, Wharton's jelly MSCs were isolated and induced to differentiate into leydig cells as promising tool for transplantation.

Material and Methods: The Leydig differentiation was induced using gonadotropins and evaluated by secretion of testosterone were determined using immunoassay and the results were compared between the experimental and control groups.

Results: Wharton's jelly MSCs induced with gonadotropins successfully differentiated to leydig cells that secret testosterone.

Conclusion: The present study showed that Wharton's jelly MSCs can differentiated in vitro to leydig cells as future therapy of male infertility.
\end{abstract}

Key Words: Mesenchymal stem cells - Wharton's jelly Gonadotrophins - Testosterone.

\section{Introduction}

INFERTILITY has been recognized as a public health problem worldwide by the World Health Organization (WHO), [1] . Infertility has been associated in patients with low testosterone levels, and has serious effects on patients' mental and

Correspondence to: Dr. Dalia H. Abouelela, E-Mail: aboeleladalia@yahoo.com social well-being [2]. Though numerous testosterone formulations have been developed, none are fully capable of replicating the physiological patterns of testosterone secretion from within the testes [3]

Testosterone is a necessary hormone that is required for normal male physiologic growth. It plays a role in the growth of genital organs in utero and initiates spermatogenesis, as well as the development of secondary sexual characteristics during puberty [4] . Low testosterone known as hypogonadism can result from a primary defect within the testes or secondarily from a disruption in the hypothalamic-pituitary-gonadal (HPG) axis [5] .

Leydig cells are the site of synthesis and secretion of testosterone [6]. Gonadotropic hormones are the primary managers of postnatal Leydig cell development. Human luteinizing hormone (LH) and chorionic gonadotropin (hCG) are glycoprotein hormones regulating development and reproductive functions by acting on the same receptor (luteinizing hormone chorionic gonadotropin receptor) (LHCGR). Although they share similar molecular structures, the two hormones have defined physiological roles [2].

Transplantation of Leydig cells has become a main treatment modality in patients with low testosterone levels $[\mathbf{7 , 8 ]}$.

Mesenchymal stem cells (MSCs) are multipotent cells have properties of self-renewal and have the ability of differentiating into adipogenic, osteogenic, chondrogenic, endothelial and neural cells. With these multiple capabilities [9] .

A large amount of these cells can be found in several regions of the human umbilical cord (HUC [10] . 
Many advantages of HUC over other stem cell tissue sources. First, HUC is seen as biological waste and discarded after birth. Its use [12]. Third, HUC cells have an increased proliferative capacity [13].

There are two current directions for stem cell therapy in male hypogonadism. The first method involves differentiating stem cells of various origins from bone marrow, adipose, or embryonic sources to adult Leydig cells. The second method involves isolating, identifying, and transplanting stem Leydig cells into testicular tissue [14].

In this study, hormone-induced method was used for differentiation of Wharton jelly mesenchymal stem cells to Leydig cells as promising therapy for hpogonadism.

\section{Subjects and Methods}

The study involved 25 pregnant females coming for delivery, for umbilical cords collection and for umbilical cord serum collection during the period from October 2016 to December 2017. Samples were aseptically collected from patients, after obtaining their consent, females with known history of hepatitis, infectious diseases, DM, severe hypertension, abortions or bad obstetric history were excluded.

The Umbilical cords were collected aseptically from full-term cesarean section patients. Cords were collected in sterile $0.9 \% \mathrm{Nacl}$ solution and were transported immediately to Clinical Pathology lab at room temperature.

Blood samples collected from patients were left at room temperature for clotting then centrifuged for $15 \mathrm{~min}$ at $3000 \mathrm{rpm}$, and then sera were collected in a single sterile falcon $50 \mathrm{ml}$ for heat inactivation by incubation at $56^{\circ} \mathrm{c}$ for $20 \mathrm{~min}$ then frozen for future use.

Wharton's jelly was cut into small pieces of about $1.5-2.5 \mathrm{~mm}$. Tissue culture plastic flasks $25 \mathrm{~cm}^{2}$ (Corning $\left.\AA\right)$ were prepared for culture by adding $5 \mathrm{ml}$ DMEM-LG with L-glutamine, cord blood serum (100 $\mathbf{g} / \mathrm{n}^{-}$), Penicillin streptomycin (100U/ml penicillin and $100 \mathrm{~g} / \mathrm{n}$ Lstreptomycin) (10 $\mathrm{g} / \mathrm{n}-\mathrm{L})$, Fungizone (0.25 $\mathrm{g} / \mathrm{n}-\mathrm{L})$ Wharton's jelly pieces were divided and distributed on tissue culture plastic flasks, the amount was added in each flask to be covered completely with media. The flasks were incubated in a horizontal position in in a humidified incubator at $37^{\circ} \mathrm{c}$ and $5 \% \mathrm{CO} 2$ At day 7 , the tissue removed by changing the medium. The flasks were washed extensively twice with warm media, and the adherent cells (MSCs) were kept in culture and were fed with fresh complete nutrient medium for 1 weeks later. These cells were kept until the outgrowth of fibroblastlike cells. At day 14, cells were examined microscopically to ensure $60-70 \%$ confluence.

Then, the leydig differentiation was induced by Gonadotropins for 21 days. The leydig cells were evaluated by post induction level of testosterone in the supernatant.

\section{Testosterone assay:}

The level of testosterone in the supernatant was measured in the experimental group as well as the control group by Immunoassay (Day 7 and 21). Results of induced testosterone production in vitro were compared between the both groups under study.

Statistical analysis: Analysis was performed using IBM SPSS Statistics version 20. Data was expressed into descriptive which include mean value, and standard Deviation (SD). Analytic which include Student's $t$-test and the Mann-Whitney test, Wilcoxon signed ranked test and F-test (one way ANOVA test).

\section{Results}

\section{Morphological identification of MSCs:}

From Umbilical cord Wharton's jelly: Attached cells were observed at 10-14 days after the initial plating. These cells then gradually reached $60 \%-$ $70 \%$ confluence at about 14 days (Fig. 1).

Detection of testosterone after MSCs induction to Leydig cells:

The cells in the experimental group give higher levels of testosterone in comparison to the control group; the highest value was obtained on the 7 st and 21 st day after induction, and the experimental group showed an increase in testosterone level with an increase in time, while the control group did not show any significant change.

Table (1): Comparison between the testosterone level in the supernatant fluid in the flasks of the experimental group and control group at day 7 and day 21 from the induction of differentian.

\begin{tabular}{llccccc}
\hline \multirow{2}{*}{ Variable (\%) } & \multicolumn{2}{c}{ Experimental group (ng/million cell) } & \multicolumn{2}{c}{ Control group (ng/million cell) } \\
\cline { 5 - 7 } & Min-Max. & Mean \pm SD. & Median & Min-Max. & Mean \pm SD. & Median \\
\hline Testosterone D7 & $0.5-1.60$ & $1.01 \pm 0.35$ & 1.00 & $0.6-0.9$ & $0.4 \pm 0.2$ & 0.3 \\
Testosterone D21 & $4.20-5.70$ & $5.00 \pm 0.45$ & 5.00 & $0.3-0.9$ & $0.5 \pm 0.3$ & 0.7 \\
\hline
\end{tabular}



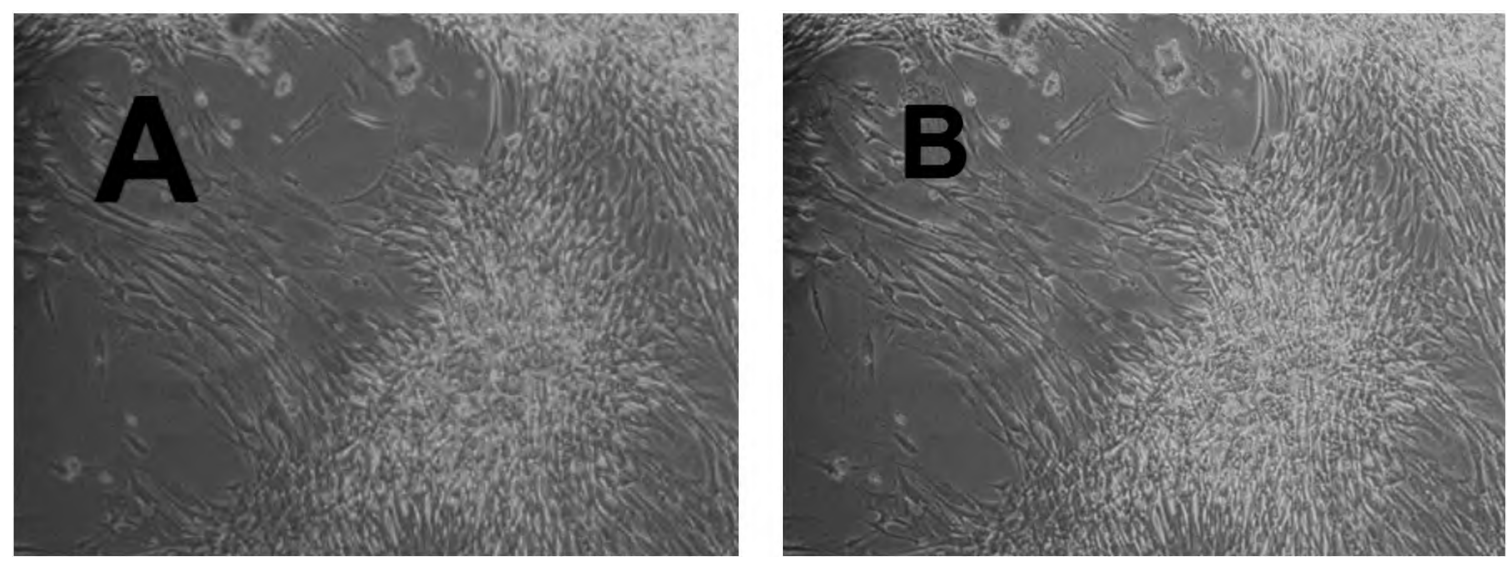

Fig. (1A): Inverted microscope image x 100 of the adherent fibroblast-like cells grew as spindle shaped cells at $60 \%-70 \%$ confluence at about 14 day. (B) Inverted microscope with phase contrast image x 100 of the adherent fibroblastlike cells grew as spindle shaped cells at $60 \%-70 \%$ confluence at about 14 day.

\section{Discussion}

Infertility affects $10-15 \%$ of couples, in human it accounts for $40-50 \%$ of infertility it affect approximately $7 \%$ of all men. Male infertility is commonly due to deficiencies in semen count and quality [15].

Leydig cells are located between the seminiferous tubules of the testis, synthesize and secrete the hormone testosterone. Testosterone plays an important role in spermatogenesis when production. While numerous testosterone formulations have been developed, none are yet fully capable of replicating the physiological patterns of testosterone secretion [16]

Multiple stem cell therapies to restore androgenic function of the testes are under investigation. Leydig cells derived from bone marrow, adipose tissue, umbilical cord, and the testes have shown promise for future therapy for hypogonadism [14]

In this study, 25 umbilical cord samples were used for isolation of MSCs and induction of their differentiation to leydig cells. 25 umbilical cord samples were used in order to isolate MSCs and to obtain cord blood serum. The success rate in isolating and culturing of MSCs were 64\% (16/25). Failure was due to contamination.

Umbilical cord was used as source of MSCs as it easily obtained, no ethically concept and give large numbers of MSCs [17]. UC-MSCs have lower immunogenicity than BM-MSCs, have immunosuppressive functions and can inhibit proliferation of T cells.

The explant method that we used was agreed by a lot [18], however it was reported that there are limitations for the isolation of UC-MSCs for clinical use. For cord lining MSCs, the isolation methods are extremely time-consuming [10]

We used low glucose DMEM and this was associated with good isolation of MSCs $[\mathbf{1 9 , 2 0 ]}$, it was reported that use of low glucose DMEM is better than high glucose for isolation of MSCs [20] Also DMEM with low glucose concentration (DMEM-LG) supported MSCs growth and maintained population doubling time up to 10 passages [21].

We used human cord blood serum (CBS) and it gave better isolation results, as it is rich in growth factors needed for the cells and was able to increase numbers of MSC from different sources like bone marrow and cord blood as well as from different species. Also CBS free of zoonotic pathogens and proteins [10].

UC-MSCs cell exhibit fibroblast-like morphology after ten days. These cells gradually reached $50 \%-60 \%$ confluence at about 14 days [22], freshly isolated WJ-MSCs normally demonstrate fibroblastlike appearance during the first culture period 1015 days and require 2-4 week until fibroblast-like adherent cells reach $80 \%-90 \%$ confluence [3]

In this study WJ-MSCs induced with Gonadotropins to differentiate to leydig cells $[\mathbf{1 , 2 5}]$

After 14 days of culturing in vitro, the MSCs exhibited the characteristics of Leydig cells and displayed the ability to secrete testosterone $[7,1,25]$

The level of testosterone secretion was measured by immunoassay, the cells in the experimental group give higher levels of testosterone in comparison to the control group; the highest value was 
obtained on the 21 day [17] differentiated UCMSCs secreted significantly more steroidogenic hormones including testosterone and cortisol. Also it was revealed that testosterone in the experimental group increased with time, while the control group did not change significantly [1] .

On the basis of our results, we conclude that: (1) Wharton jelly mesenchymal stem cells can be easily isolated and cultured in vitro and, (2) Gonadotropin induce the differentiation of Leydig cells and establish the cellular model. MSCs may be therapeutic potential for the clinical treatment of patients who have complete loss of endogenous Leydig cell due to chemotherapy or radiation. They may find long-term success with the transplantation of cells with more regenerative capacity.

\section{References}

1- HOU L., DONG Q., WU Y.J., SUN Y.X., GUO Y.Y. and HUOYH C.: Gonadotropins facilitate potential differentiation of human bone marrow mesenchymal stem cells into Leydig cells in vitro. Kaohsiung Journal of Medical Sciences, 32: 1e9, 2016.

2- CHOI J. and SMITZ J.: Luteinizing hormone and human chorionic gonadotropin: Origins of difference. Mol. Cell. Endocrinol., 383 : 203-13, 2014.

3- LEVINE G.N., D'AMICO A.V., BERGER P., CLARK P.E., ECKEL R.H., KEATING N.L., MILANI R.V., SAGALOWSKY A.I., SMITH M.R. and ZAKAI N.: Androgen deprivation therapy in prostate cancer and cardiovascular risk: A science advisory from the American Heart Association, American Cancer Society, and American Urological Association: Endorsed by the American Society for Radiation Oncology. CA. Cancer. J. Clin., 16; 121 (6): 833-40, 2010.

4- ARAUJO A.B., DIXON J.M., SUAREZ E.A., MURAD M.H., GUEY L.T. and WITTERT G.A.: Clinical review: Endogenous testosterone and mortality in men: A systematic review and meta-analysis. J. Clin. Endocrinol. Metab. 96 (10): 3007-3019, 2011.

5- YEAP B.B., HYDE Z., ALMEIDA O.P., NORMAN P.E., CHUBB S.A., JAMROZIK K., FLICKER L. and HANKEY G.J.: Lower testosterone levels predict incident stroke and transient ischemic attack in older men. J. Clin. Endocrinol. Metab., 94: 2353-2359, 2009.

6- HAIDER S.G.: Cell biology of Leydig cells in the testis. International Review of Cytology, 233 : 181-241, 2004.

7- RICCETTI L., DE PASCALI F., GILIOLI L., POTÌF, GIVA L.B., MARINO M., TAGLIAVINI S., TRENTI T. , FANELLI F., MEZZULLO M., PAGOTTOU, SIMONI M. and CASARINI L.: Human LH and hCG stimulate differently the early signalling pathways but result in equal testosterone synthesis in mouse Leydig cells in vitro. Reproductive Biology and Endocrinology, 15: 2, 2017.

8- MÄ KELÄ J.A., TOPPARI J., RIVERO-MÜLLER A, VENTELÄS.: Reconstruction of mouse testicular cellular microenvironments in long-term seminiferous tubule culture. PLoS One., 9: e90088, 2014.

9- CAPLAN A.: Mesenchymal stem cells in Regenerative medicine. Handbook of Stem Cells, 2: 493-502, 2013.

10- WATSON N., DIVERS R., KEDAR R., MEHINDRU A., MEHINDRU A., BORLONGAN M.C. and BORLONGAN C.V.: Discarded Wharton's Jelly of the Human Umbilical Cord: A Viable Source for Mesenchymal Stem Cells. International Society for Cellular Therapy, 17 (1): 18-24, 2015.

11- BATSALI A.K., KASTRINAKI M.C., PAPADAKI H.A. and PONTIKOGLOU C.: Mesenchymal Stem Cells Derived from Wharton's Jelly of the Umbilical Cord: Biological Properties and Emerging Clinical Applications. Current Stem Cell Research and Therapy, 8 (2): 144-155, 2013.

12- CHO P.S., MESSINA D.J., HIRSH E.L., CHI N., GOLDMAN S.N., LO D.P., HARRIS I.R., POPMA S.H., SACHS D.H. and HUANG C.A.: Immunogenicity of umbilical cord tissue-derived cells. Blood Journal, 111 (1): 430438,2008 .

13- CONCONI M.T., DI LIDDO R., TOMMASINI M., CALORE C. and PARNIGOTTO P.P.: Phenotype and Differentiation Potential of Stromal Populations Obtained from Various Zones of Human Umbilical Cord: An Overview. The Open Tissue Engineering and Regenerative Medicine Journal, 4: 6-20, 2011.

14- PEAK T.C., HANEY N.M., WANG W., DELAY K.J. and HELLSTROM W.J.: Stem cell therapy for the treatment of Leydig cell dysfunction in primary hypogonadism. World J. Stem. Cells, 8 (10): 306-3 15, 2016.

15- INHORN M.C. and PATRIZIO P.: Infertility around the globe: New thinking on gender, reproductive technologies and global movements in the 21 st century Hum. Reprod Update, 201 (21): 411-426, 2015.

16- HAIDER S.G.: Cell biology of Leydig cells in the testis. Int. Rev. Cytol., 233 : 181-241, 2004.

17- WEI X., PENG G., ZHENG S. and WU X.: Differentiation of umbilical cord mesenchymal stem cells into steroidogenic cells in comparison to bone marrow mesenchymal stem cells. Cell. Prolif., 45: 101-110, 2012.

18- MAJORE I., MORETTI P., STAHL F., HASS R. and KASPER C.: Growth and Differentiation Properties of Mesenchymal Stromal Cell Populations Derived from Whole Human Umbilical Cord. Stem. Cell. Rev. and Rep., 7: 17-31, 2011.

19- DEOROSAN B. and NAUMAN E.: The role of glucose, serum, and three-dimensional cell culture on the metabolism of bone marrow-derived mesenchymal stem cells. Dev. Cell, 16: 209-221, 2011.

20- AYATOLLAHI M., SALMANI M., GERAMIZADEH B., TABEI S.Z., SOLEIMANI M. and SANATI M.H.: Conditions to improve expansion of human mesenchymal stem cells based on rat samples. World J. Stem. Cells, 26, 4 (1): $1-8,2012$.

21- PAL R., HANWATE M., JAN M. and TOTEY S.: Phenotypic and functional comparison of optimum culture conditions for upscaling of bone marrow-derived mesenchymal stem cells. J. Tissue. Eng. Regen. Med., 3 (3), 163-174, 2009. 
22- KOLIAKOS I., TSAGIAS N. and KARAGIANNIS V. Mesenchymal cells isolation from Wharton's jelly, in perspective to clinical applications. Journal of Biological Research-Thessaloniki, 16: 194-201, 2011.

23- NAGAMURA-INOUE T. and HE H.: Umbilical cordderived mesenchymal stem cells: Their advantages and potential clinical utility. World J. Stem. Cells., 26, 6 (2): 195-202, 2014.

24- GUO J., MA X., WANG C.Q., GE Y.F., LIAN Q.Q., et al.: "Effects of luteinizing hormone and androgen on the development of rat progenitor Leydig cells in vitro and in vivo." Asian. J. Androl., 15 (5): 685-91, 2013.

25- LUE Y., ERKKILA K., LIU P.Y., MA K., WANG C., HIKIM A.S., et al.: Fate of bone marrow stem cells transplanted into the testis: Potential implication for men with testicular failure. Am. J. Pathol., 170: 899e908, 2007.

26- XING X., ZHANG Z., ZHONG L., JU G., ZOU X., ZHU Y. and SUN J.: Differentiation of human umbilical cord mesenchymal stem cells into steroidogenic cells in vitro. Experimental and Therapeutic Medicine, 12: 3527-3534, 2016

\section{تقيييم دور الجونادوتروبين فى تمايز الخلايا الجذامية الوسيطة

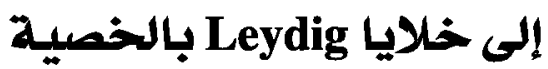

العقم عند الرجال هو عدم حدوث حمل في زفجة كاملة الخصوبة، والعقم عند الرجال سبيه عادة نقص في السائل المنوى أوضعف كفائته

هأرتبط بالمرضى الذين يعانون من إنخفاض مستويات هرمون التستوبستيرف وله إنعكاساث خطيرة على النمو الذهنى والأجتماعى للذكى .

العلاج بالهرمونات البديلة للمرضى الذين يعانهف من فثل الغدد التناسلية يحتاجن له طوال حياتهم مما سبب لهم أمراض السرطان ولهذا فهم بحاجة إلى علاج بلديل.

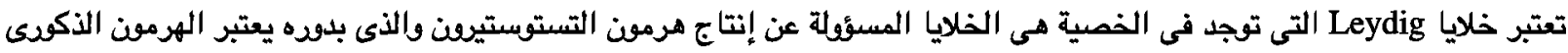
الرئيسى المسئفل عن الإنجاب والصفاظ على الصفات الذكي فئية الثانوية.

قد ينجم نضوب خلايا Leydig من مشاكل مختلفة قد تكن عيوب خلقية، أو من حوادث، أو الإشعاع، أو العلاج الكيميائى وغيرها، ويتتج فقد خلايا Leydig إنخفاض مستوى التستوبيتيرن.

ولقد أصبحت زراعة خلايا Leydig تمايزها من الخلايا الجذعية الوبسيطة بمساعدة الجونادتروبين أحد الطرق الرئيسية في علاج إخفاض فئس هرمون التستوستيرن، ووجد أنه عند زراعة الخلايا أنها تشارك في تتظيم إفراز الأندرجين في ظروف فيسيسيولويجية طبيعية وتعتبر الخلايا

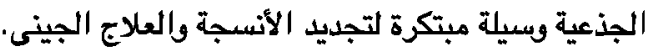

الهدف من العمل: في هذه الدراسة، هو فصل الخلايا الجذعية للتمايز إلى خلايا Leydig.

ويتم الأستدلال على تمايز الخلايا الجذعية الوسيطة إلى خلايا Leydig عن طريق قياس مستوى هرمون التستوبتيرون التى قا مت بإنتاجه

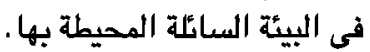

